\title{
In vitro screening of rice genotypes using polyethylene glycol under drought stress
}

\author{
J Akte*, S Yasmin, MJH Bhuiyan, F Khatun, J Roy, K Goswami \\ USDA Biotechnology laboratory, Bangladesh Agricultural University, Mymensingh-2202, Bangladesh
}

\begin{abstract}
Five rice varieties viz. Binadhan-4, Binadhan-5, Binadhan-6, Binadhan-10 and Iratom-24 were evaluated in vitro under different water stress conditions. Several parameters such as germination percentage, shoot length, root length, shoot-root ratio, fresh weight, dry weight, turgid weight, relative water content and proline accumulation were studied. Drought condition was created by MS medium supplemented with five treatments of PEG, with a control such as $0 \%, 1 \%, 2 \%, 3 \%$ and $4 \%$ of PEG. The highest germination $(100 \%)$ was found in the variety Binadhan-10 under low water stress conditions induced by $1 \%$ PEG. Similarly, the highest percentage of germination was found in all varieties under control condition ( $0 \% \mathrm{PEG})$. The lowest percentage of germination was obtained in the variety Iratom-24. But under severe stress (4\% PEG), the highest percentage of germination was found only in the variety Binadhan-10. Moreover, the variety Binadhan-10 was found to be the best at 4\% PEG for shoot length, root length, shoot-root ratio, relative water content and also the best at $1 \%$ PEG for fresh weight, dry weight, turgid weight. Water stress decreased relative water content and increased proline accumulation in rice. The highest relative water content was recorded in the variety Binadhan-10 and the lowest value recorded in the variety Binadhan-5. The highest proline content was obtained from the binadhan- 6 at the highest treatment (4\% PEG). Binadhan-10 showed the best performance almost in all the parameters under drought stress because of its own nature of tolerancy.
\end{abstract}

Key words: Drought tolerance, rice, relative water content, water stress.

Progressive Agriculturists. All rights reserve *Corresponding Author: author-juliaakter90@gmail.com

\section{Introduction}

Drought is one of the major abiotic stresses that severely affect and reduce the yield and productivity of food crops worldwide up to $70 \%$ (Kaur et al., 2008; Thakur et al., 2010; Akram et al., 2013). The response of plants to drought stress is complex and involves changes in their morphology, physiology and metabolism. Much more extensive loss of water can lead to accumulation of reactive oxygen species (ROS), which disrupts metabolism and cell structure and eventually the enzyme-catalyzed reactions and finally may result in the death of plant (Jaleel et al., 2008; Phung et al., 2011).

Rice (Oryza sativa L.) is the most important cereal crop in the world and it is the primary source of food and calories for about half of mankind (Khush,
2005). Rice constitutes the most important economic activity and the primary source of income and employment for more than 100 million households in Asia and Africa (FAO, 2004). The predominantly rice-growing areas in Asia (130 million hectares, more than $85 \%$ of the total world rice production) are often threatened by severe abiotic stresses. Bangladesh is faceing rice production constraints such as drought, lack of irrigation facilities, flooding, salinity of soils, coupled with fluctuation of commercial prices. Climate change has rendered several areas unsuitable for rice cultivation. The impact of drought spreads disproportionately amongst regions of Bangladesh. There is a popular impression in Bangladesh that the northwestern 
districts of Rajshahi, Dinajpur, Rangpur, Bogra, and Pabna are particularly drought-prone. The aim of this work was to study the comparative effects of different concentrations of PEG (drought inducer) on growth characteristics and proline accumulation of five rice varieties and to develop a rapid and suitable screening protocol for rice against drought conditions.

\section{Materials and Methods}

The experiment was carried out during the period from January, 2015 to June, 2015 at USDA Biotechnology Laboratory and Laboratory of the Department of Biochemistry and Molecular Biology, Bangladesh Agricultural University, Mymensingh. Seeds of five rice varieties (Binadhan-4, 5, 6, 10 and Iratom-24) were collected from the Bangladesh Institute of Nuclear Agriculture (BINA), Mymensingh. Sterilized mature seeds of five varieties of rice were inoculated into test tubes containing $10 \mathrm{ml}$ MS medium with PEG at different concentrations viz. $\mathrm{T}_{0}=0 \%$ ( control or no PEG), $\mathrm{T}_{1}=1 \%$ PEG, $\mathrm{T}_{2}=2 \%$ PEG, $\mathrm{T}_{3}=3 \%$ PEG and $\mathrm{T}_{4}=4 \%$ PEG with three replication. Cultures were maintained at $25^{\circ} \mathrm{C}$ temperature under light. MSTATC software was used to analyze the data by ANOVA function.

\section{Percentage of germination}

Germination percentage

$=\frac{\text { Number of seeds germinated and became geedlinga }}{\text { Number of sefds get for germinat on }} \times 100$

Shoot length, root length, shoot-root ratio, total fresh weight, total dry weight and turgid weight

At the 21st day, the seedling from the test tube was taken out with the help of forceps. Then shoot length, root length, were measured in centimeter by a graduated scale and total length was calculated from the recorded data. Shoot and root were weighted in gram by electrical balance in fresh, dry and turgid condition.

\section{Relative water content}

The leaves were cut, and the relative water content $(R W C)$ was determined according to the procedures by Ghannoum et al. (2002). The relative water content of leaf was determined as follows:

\begin{abstract}
$R W C=($ fresh weight - dried weight $) /($ fully turgid weight - dried weight) $\times 100$

To determine the fully turgid weight, the leaves were kept in distilled water in the darkness at $4^{0} \mathrm{c}$ to minimize respiration losses until they reached a constant weight (full turgor, typically after $12 \mathrm{~h}$ ). The leaf dry weight was obtained after $48 \mathrm{~h}$ at $70^{\circ} \mathrm{C}$ in an oven. Three replicates were obtained per treatment.
\end{abstract}

\section{Proline determination}

Free proline was extracted from the leaves of plants using aqueous sulfosalicylic acid. The filtrate $(1 \mathrm{ml})$ was mixed with equal volumes of glacial acetic acid and ninhydrin reagent $(1.25 \mathrm{~g}$ ninhydrin, $30 \mathrm{ml}$ of glacial acetic acid, $20 \mathrm{ml} 6 \mathrm{NH}_{3} \mathrm{PO}_{4}$ ) and incubated for $1 \mathrm{~h}$ at $100^{\circ} \mathrm{C}$. The reaction was stopped by placing the test tubes in cold water. The samples were rigorously mixed with $4 \mathrm{ml}$ toluene. The light absorption of toluene phase was estimated at 520 nm using Pharmacia LKB- Novaspec II model spectrophotometer. The proline concentration was determined using a standard curve. Free proline content was expressed as $\mathrm{mg} / 100 \mathrm{~g}$ of plant parts.

\section{Results and Discussion}

The genotypes varied significantly for the percentage of germination, shoot length, root length, shoot-root ratio, total fresh weight, total dry weight, turgid weight, relative water content and proline accumulation.

\section{Response among the varieties}

The mean squares of rice varieties for the percentage of germination, shoot length, root length, shoot-root ratio, total fresh weight, total dry weight, turgid weight, relative water content and proline accumulation are highly significant. The highest percentage of germination was obtained in the variety Binadhan-10 (88.00\%) which was significantly similar with the variety Binadhan-4 (85.33\%) (Table 1).

Maximum value of shoot length $(14.76 \mathrm{~cm})$ was obtained for the variety Binadhan-10 which was significantly higher than Binadhan-6 (14.34cm) (Table 2), whereas shoot length in Binadhan-6 and 
Binadhan-4 was indifferent. The lowest shoot length was observed for the variety Binadhan-5 $(13.74 \mathrm{~cm})$. The highest root length was found in Binadhan-10 $(4.860 \mathrm{~cm})$ and the lowest value was found in Binadhan-5 (4.136 cm) which was significantly similar with Binadhan-4 $(4.282 \mathrm{~cm})$ (Table 2). The root length of all upland rice varieties exhibited significant reduction at the highest drought level as compared to control. Reduction of root length under stress conditions may due to an impediment of cell division (Fraser et al., 1990). The highest shoot root ratio was found in Binadhan-4 (3.361) which was significantly similar with Binadhan-5 (3.359). The lowest value was found in Binadhan-10 (3.037) followed by Iratom-24 (3.057), Binadhan-6 (3.137) (Table 2).

Table 1. Effect of varieties on germination of seedling of in vitro rice varieties

\begin{tabular}{lccc}
\hline Varieties & $\begin{array}{c}\text { No. of } \\
\text { seeds } \\
\text { inoculated }\end{array}$ & $\begin{array}{c}\text { No. of } \\
\text { seeds } \\
\text { germination }\end{array}$ & $\begin{array}{c}\text { Germination } \\
(\%)\end{array}$ \\
\hline Binadhan-4 & 75 & 64 & $85.33 \mathrm{a}$ \\
Binadhan-5 & 75 & 56 & $74.67 \mathrm{~b}$ \\
Binadhan-6 & 75 & 54 & $72.00 \mathrm{~b}$ \\
Binadhan- & 75 & 66 & $88.00 \mathrm{a}$ \\
10 & & & \\
Iratom-24 & 75 & 44 & $58.67 \mathrm{c}$ \\
LSD & & & 2.93 \\
Level of & & & $* *$ \\
significance & & & \\
CV (\%) & & & 5.28 \\
\hline
\end{tabular}

Table 2. Effect of varieties on shoot length, root length and shoot-root ratio of seedling of in vitro rice varieties

\begin{tabular}{lccc}
\hline Varieties & $\begin{array}{c}\text { Shoot } \\
\text { Length } \\
(\mathrm{cm})\end{array}$ & $\begin{array}{c}\text { Root } \\
\text { length } \\
(\mathrm{cm})\end{array}$ & $\begin{array}{c}\text { Shoot- } \\
\text { root } \\
\text { ratio }\end{array}$ \\
\hline Binadhan-4 & $14.30 \mathrm{c}$ & $4.282 \mathrm{c}$ & $3.361 \mathrm{a}$ \\
Binadhan-5 & $13.74 \mathrm{~d}$ & $4.136 \mathrm{c}$ & $3.359 \mathrm{a}$ \\
Binadhan-6 & $14.34 \mathrm{~b}$ & $4.584 \mathrm{~b}$ & $3.137 \mathrm{~b}$ \\
Binadhan-10 & $14.76 \mathrm{a}$ & $4.860 \mathrm{a}$ & $3.037 \mathrm{~b}$ \\
Iratom-24 & $13.99 \mathrm{c}$ & $4.584 \mathrm{~b}$ & $3.057 \mathrm{~b}$ \\
LSD & 0.198 & 0.146 & 0.1198 \\
Level of & $* *$ & $* *$ & $* *$ \\
significance & & & \\
CV $(\%)$ & 1.90 & 4.44 & 1.71 \\
\hline
\end{tabular}

The highest fresh weight, dry weight and relative water content was obtained in the variety Binadhan10 (Table 3). The highest total turgid weight was found in Binadhan-6 (0.3582g) which was significantly similar with Binadhan-10 (Table 3). Maximum weight of proline content was obtained for the variety Binadhan-6 (9.988mg) which was similar to Binadhan-4 (9.845mg) (Table 4). Proline accumulates under stress also supplies energy for survivor and growth and thereby helps the plants to tolerate stress condition (Kumar et al., 2011). Thus, the ptoline content is a good indicator for screening drought tolerant varieties in water stress condition (Bayoumi et al., 2008; Kumar et al., 2011; Rahdari et al., 2012).

\section{Effect of different treatments}

Mean square of different concentrations of PEG $\left(\mathrm{T}_{0}\right.$ $=0 \%$ (control or no PEG), $\mathrm{T}_{1}=1 \%$ PEG, $\mathrm{T}_{2}=2 \%$ PEG, $\mathrm{T}_{3}=3 \%$ PEG, $\mathrm{T}_{4}=4 \%$ PEG) were highly significant. Under control condition ( $0 \%$ PEG), the highest percentage of germination, shoot length, root length, shoot-root ratio, total fresh weight, total dry weight, turgid weight and relative water content was recorded (Table 5, 6, 7). Govindaraj (2010) was revealed that severe drought (PEG-induced) stress can negatively affect germination percentage. Among the different treatments of PEG, MS medium supplemented with 4\% PEG that was found the most effective for proline content (14.583mg). The accumulation of proline was higher under water stress treatment than the control treatment for all the rice varieties (Table 8 ).

The lowest value of germination percentage, shoot length, root length, shoot-root ratio, total fresh weight, total dry weight, turgid weight and relative water content was recorded for the treatment of $4 \%$ PEG but the lowest value of proline content was recorded for the treatment of $0 \%$ PEG. Luma et al. (2011) revealed that PEG at high concentrations (6 \& $9 \%$ ) caused a significant decrease in callus fresh weight compared with control.

The lowest value of relative water content was recorded for the treatment of $4 \%$ PEG but the lowest value of proline content was recorded for the 
treatment of $0 \%$ PEG. Our results are in accordance with previous studies, water relation decreased in all plant species in response to drought condition such as Wheat (Siddique et al., 2000), Hibiscus rosasinensis (Egilla et al., 2005), Plantago ovata and
Plantago psyllium (Rahimi et al., 2010) and chickpea (Rahbarian et al., 2011). Luma et.al (2011) was showed a significant increase in callus proline along with increasing PEG concentrations. The highest content of proline was observed at 9\% PEG.

Table 3. Effect of varieties on fresh weight, dry weight, turgid weight and relative water content of seedling of in vitro rice varieties

\begin{tabular}{lcccc}
\hline Varieties & $\begin{array}{c}\text { Fresh } \\
\text { weight }(\mathrm{g})\end{array}$ & Dry weight $(\mathrm{g})$ & $\begin{array}{c}\text { Turgid weight } \\
(\mathrm{g})\end{array}$ & $\begin{array}{c}\text { Relative water content } \\
(\%)\end{array}$ \\
\hline Binadhan-4 & $0.0877 \mathrm{~d}$ & $0.0677 \mathrm{e}$ & $0.3162 \mathrm{~d}$ & $8.113 \mathrm{~b}$ \\
Binadhan-5 & $0.0977 \mathrm{c}$ & $0.0787 \mathrm{~d}$ & $0.3277 \mathrm{c}$ & $7.550 \mathrm{c}$ \\
Binadhan-6 & $0.117 \mathrm{~b}$ & $0.0971 \mathrm{~b}$ & $0.3582 \mathrm{a}$ & $7.889 \mathrm{bc}$ \\
Binadhan-10 & $0.126 \mathrm{a}$ & $0.101 \mathrm{a}$ & $0.3570 \mathrm{a}$ & $9.659 \mathrm{a}$ \\
Iratom-24 & $0.115 \mathrm{~b}$ & $0.0914 \mathrm{c}$ & $0.3443 \mathrm{~b}$ & $9.358 \mathrm{a}$ \\
LSD & 0.00349 & 0.00137 & 0.00950 & 0.505 \\
Level of & $* *$ & $* *$ & $* *$ & $*$ \\
significance & & & & \\
CV $(\%)$ & 4.29 & 5.19 & 3.63 & 8.08 \\
\hline
\end{tabular}

Table 4. Effect of varieties on proline content of seedling of in vitro rice varieties

\begin{tabular}{lc}
\hline Varieties & $\begin{array}{c}\text { Proline } \\
\text { content }(\mathrm{mg} / 100 \mathrm{~g})\end{array}$ \\
\hline Binadhan-4 & $9.845 \mathrm{a}$ \\
Binadhan-5 & $8.896 \mathrm{~b}$ \\
Binadhan-6 & $9.988 \mathrm{a}$ \\
Binadhan-10 & $8.029 \mathrm{c}$ \\
Iratom-24 & $9.515 \mathrm{ab}$ \\
LSD & 0.6596 \\
Level of significance & $* *$ \\
CV $(\%)$ & 3.26 \\
\hline
\end{tabular}

Table 5. Effect of PEG treatments on germination of seedling of in vitro rice varieties

\begin{tabular}{lccc}
\hline Treatments & $\begin{array}{c}\text { No. of seeds } \\
\text { inoculated }\end{array}$ & $\begin{array}{c}\text { No. of seeds } \\
\text { germination }\end{array}$ & $\begin{array}{c}\text { Germination } \\
(\%)\end{array}$ \\
\hline $\mathrm{T}_{0}(0 \%$ PEG $)$ & 75 & 72 & $96.00 \mathrm{a}$ \\
$\mathrm{T}_{1}(1 \%$ PEG $)$ & 75 & 60 & $80.00 \mathrm{~b}$ \\
$\mathrm{~T}_{2}(2 \%$ PEG $)$ & 75 & 56 & $74.67 \mathrm{c}$ \\
$\mathrm{T}_{3}(3 \%$ PEG $)$ & 75 & 50 & $66.67 \mathrm{~d}$ \\
$\mathrm{~T}_{4}(4 \%$ PEG $)$ & 75 & 46 & $61.33 \mathrm{e}$ \\
$\mathrm{LSD}_{0.05}$ & & & 2.93 \\
Level of & & & $* *$ \\
significance & & & 5.28 \\
CV (\%) & & & \\
\hline
\end{tabular}

\section{Interaction effect of varieties and treatments}

The effect of interaction between varieties and treatments differ significantly on germination percentage, shoot length, root length, shoot-root ratio, total fresh weight, total dry weight, turgid weight, relative water content and proline accumulation (Figure 1: A-I). The percentage of germination varied from $46.67 \%$ to $100 \%$ (Figure 1 : G). Maximum germination percentage, shoot length was recorded for Binadhan-4, when seeds were cultured on MS medium supplemented with $0 \%$ PEG. The lowest shoot length was observed for Iratom-24 that was treated with 4\% PEG. The fresh weight varied from $0.0667 \mathrm{~g}$ to $0.1610 \mathrm{~g}$ (Figure 1: A). The root length varied from $3.24 \mathrm{~cm}$ to $5.37 \mathrm{~cm}$ (fig. 1: B).

The shoot length varied from $12.88 \mathrm{~cm}$ to $15.76 \mathrm{~cm}$ (Figure 1: C). The dry weight varied from $0.0500 \mathrm{~g}$ to $0.1300 \mathrm{~g}$ (Figure 1: D). The turgid weight varied from $0.2990 \mathrm{~g}$ to $0.4010 \mathrm{~g}$ (Figure 1: E). The relative water content varied from $11.43 \%$ to $3.740 \%$ (Figure 1: H). Maximum root length, fresh weight, dry weight, turgid weight and relative water content were recorded for Binadhan-10, when seeds were cultured 
on MS medium supplemented with 0\% PEG. The lowest root length was observed for Binadhan-5 that was treated with 4\% PEG. The shoot-root ratio varied from 2.93 to 3.920 (Figure 1: I). Maximum shoot-root ratio was recorded for Iratom-24, when seeds were cultured on MS medium supplemented with $1 \%$ PEG. The lowest shoot-root ratio was observed for Binadhan-4 that was treated with $4 \%$ PEG. The lowest fresh weight, dry weight and turgid weight was observed for Binadhan-4 that was treated with 3\% PEG which was significantly similar with $4 \%$ PEG

Table 6. Effect of PEG treatments on shoot length, root length and shoot-root ratio of seedling of in vitro rice varieties

\begin{tabular}{lccc}
\hline Treatments & Shoot length $(\mathrm{cm})$ & Root length $(\mathrm{cm})$ & Shoot-root ratio \\
\hline $\mathrm{T}_{0}(0 \%$ PEG $)$ & $15.44 \mathrm{a}$ & $5.022 \mathrm{a}$ & $3.077 \mathrm{~b}$ \\
$\mathrm{~T}_{1}(1 \%$ PEG $)$ & $14.86 \mathrm{~b}$ & $4.732 \mathrm{~b}$ & $3.147 \mathrm{~b}$ \\
$\mathrm{~T}_{2}(2 \%$ PEG $)$ & $14.09 \mathrm{c}$ & $4.628 \mathrm{~b}$ & $3.045 \mathrm{~b}$ \\
$\mathrm{~T}_{3}(3 \%$ PEG $)$ & $13.62 \mathrm{~d}$ & $4.166 \mathrm{c}$ & $3.283 \mathrm{a}$ \\
$\mathrm{T}_{4}(4 \%$ PEG $)$ & $13.11 \mathrm{e}$ & $3.898 \mathrm{~d}$ & $3.401 \mathrm{a}$ \\
$\mathrm{LSD}_{0.05}$ & 0.198 & 0.146 & 0.1198 \\
Level of & $* *$ & $* *$ & $* *$ \\
significance & & & 1.71 \\
$\mathrm{CV}(\%)$ & 1.90 & 4.44 & \\
\hline
\end{tabular}

Table 7. Effect of PEG treatments on fresh weight, dry weight, turgid weight and relative water content of seedling of in vitro rice varieties

\begin{tabular}{lcccc}
\hline Treatments & Fresh weight $(\mathrm{g})$ & $\begin{array}{c}\text { Dry weight } \\
(\mathrm{g})\end{array}$ & Turgid weight $(\mathrm{g})$ & $\begin{array}{c}\text { Relative water content } \\
(\%)\end{array}$ \\
\hline $\mathrm{T}_{0}(0 \%$ PEG $)$ & $0.1386 \mathrm{a}$ & $0.0255 \mathrm{a}$ & $0.1675 \mathrm{a}$ & $10.92 \mathrm{a}$ \\
$\mathrm{T}_{1}(1 \%$ PEG $)$ & $0.1218 \mathrm{~b}$ & $0.0242 \mathrm{~b}$ & $0.1556 \mathrm{~b}$ & $9.768 \mathrm{~b}$ \\
$\mathrm{~T}_{2}(2 \%$ PEG $)$ & $0.1114 \mathrm{c}$ & $0.0224 \mathrm{c}$ & $0.1454 \mathrm{c}$ & $8.808 \mathrm{c}$ \\
$\mathrm{T}_{3}(3 \%$ PEG $)$ & $0.0916 \mathrm{~d}$ & $0.0191 \mathrm{~d}$ & $0.1182 \mathrm{~d}$ & $7.307 \mathrm{~d}$ \\
$\mathrm{~T}_{4}(4 \%$ PEG $)$ & $0.0820 \mathrm{e}$ & $0.01679 \mathrm{e}$ & $0.1090 \mathrm{e}$ & $5.765 \mathrm{e}$ \\
$\mathrm{LSD}_{0.05}$ & 0.00349 & 0.00137 & 0.00950 & 0.505 \\
Level of & $* *$ & $* *$ & $* *$ & $* *$ \\
significance & & & & 8.63 \\
$\mathrm{CV}(\%)$ & 4.29 & 5.19 & & 8.08 \\
\hline
\end{tabular}

Table 8. Effect of PEG treatments on proline content of seedling of in vitro rice varieties

\begin{tabular}{lc}
\hline Treatments & $\begin{array}{c}\text { Proline content } \\
(\mathrm{mg} / 100 \mathrm{~g})\end{array}$ \\
\hline $\mathrm{T}_{0}(0 \%$ PEG $)$ & $4.458 \mathrm{e}$ \\
$\mathrm{T}_{1}(1 \%$ PEG $)$ & $6.861 \mathrm{~d}$ \\
$\mathrm{~T}_{2}(2 \%$ PEG $)$ & $8.961 \mathrm{c}$ \\
$\mathrm{T}_{3}(3 \%$ PEG $)$ & $11.410 \mathrm{~b}$ \\
$\mathrm{~T}_{4}(4 \%$ PEG $)$ & $14.583 \mathrm{a}$ \\
$\mathrm{LSD}_{0.05}$ & 0.6596 \\
Level of significance & $* *$ \\
$\mathrm{CV}(\%)$ & 3.26 \\
\hline
\end{tabular}

The proline content varied from $3.913 \mathrm{mg}$ to $15.427 \mathrm{mg}$ (Figure 1: F). Maximum proline content was recorded for Iratom-24, when seeds were cultured on MS medium supplemented with 4\% PEG. The lowest value of proline content was recorded for Binadhan-10, when seeds were cultured on MS medium supplemented with 0\% PEG. After 15 days, variation among the varieties for MS medium supplemented with 0\% PEG and 4\% PEG (Figure 2). 

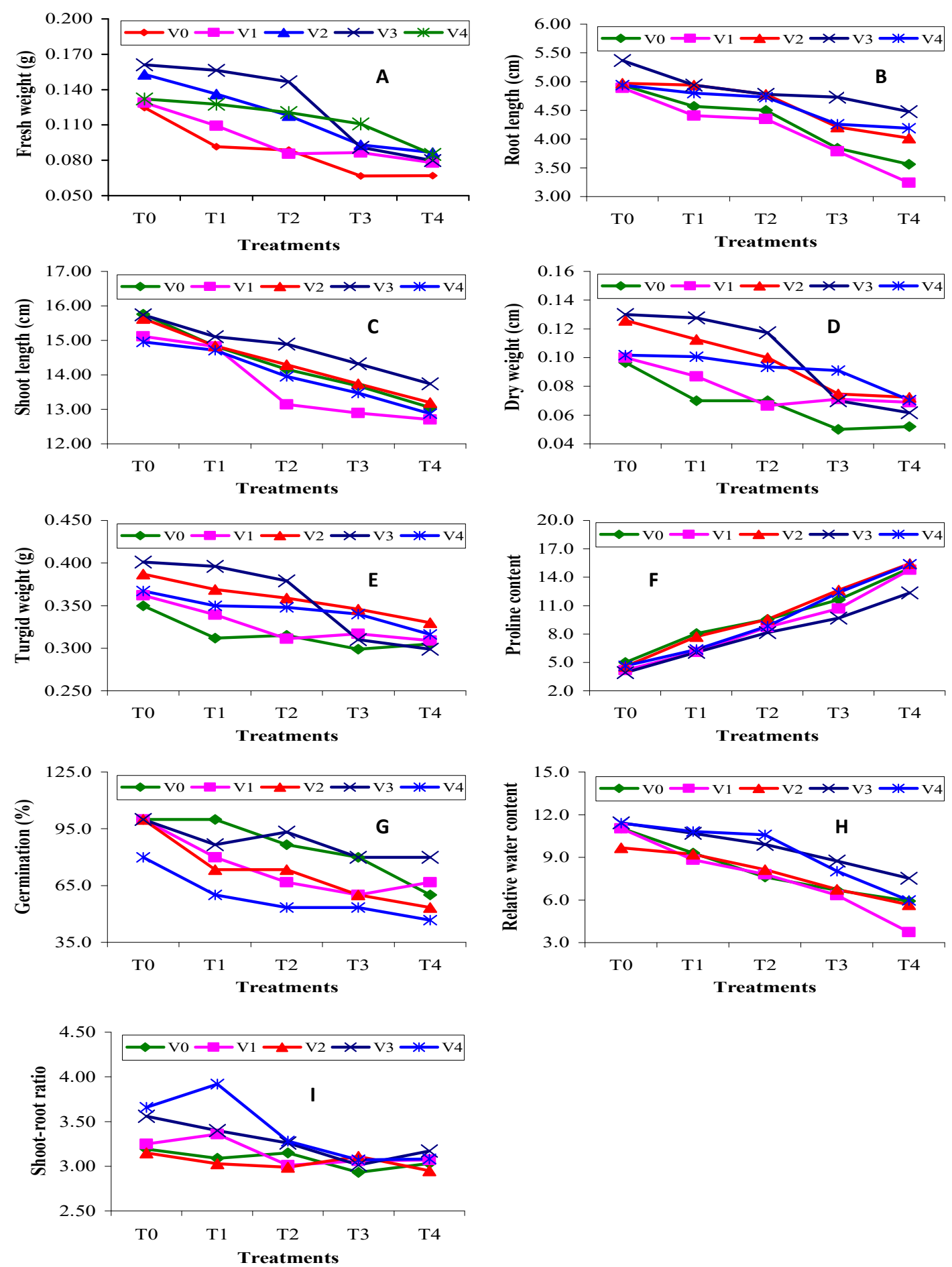

Figure 1. Effect of interaction between varieties and treatments on fresh weight (A), root length (B), shoot length $(\mathrm{C})$, dry weight $(\mathrm{D})$, turgid weight $(\mathrm{E})$, proline content $(\mathrm{F})$, germination percentage $(\mathrm{G})$, relative water content $(\mathrm{H})$ and shoot-root ratio $(\mathrm{I}), \mathrm{V}_{0}=$ Binadhan $-4, \mathrm{~V}_{1}=$ Binadhan $-5, \mathrm{~V}_{2}=$ Binadhan-6, 

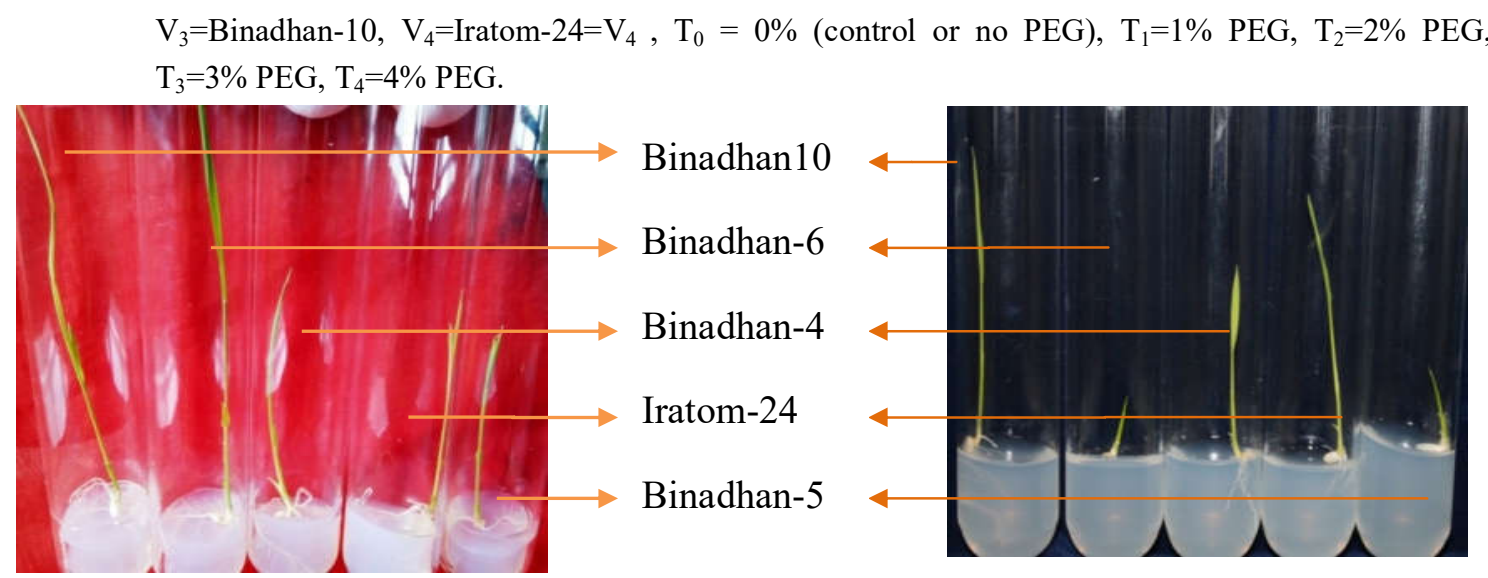

Figure 2. Variation among the varieties for MS medium supplemented with $0 \%$ PEG (a) and 4\% PEG (b) (after 15 days).

\section{Conclusion}

For the percentage of germination, Binadhan-10 performed the best followed by other varieties at control condition ( $0 \%$ PEG) and even Binadhan-10 also performed the best at $3 \%$ and $4 \%$ of $\mathrm{PEG}$ treatment. Similarly, it also showed that Binadhan-10 performed the best for length of root and shoot, total fresh weight, total dry weight under severe treatment (4\% PEG). But the variety Binadhan-10 did the best for turgid weight under 3\% PEG treatment. The highest relative water content was recorded for the variety Binadhan-10 under control condition $(0 \%$ PEG). The highest proline content was observed in the variety Binadhan- 6 under 4\% PEG treatment. Considering all the parameters for all varieties when raised in vitro upto seedling stage without any drought stress $(0 \%$ PEG ), it was found that the variety Binadhan-10 showed the best performance in all cases. Similarly, the variety Binadhan-10 was performed the best even against the highest degree of drought stress because of its tolerancy nature.

\section{References}

Akram HM, Ali A, Sattar HSU, Rehman and Bibi A (2013). Impact of water deficit stress on various physiological and agronomic traits of three Basmati rice (Oryza sativa L) cultivars. Journal of Animal Plant Science, 23(5): 1415-1423.

Bayoumi TY, Eid MH and Metwali EM (2008). Application of physiological and biochemical indices as a screening technique for drought tolerance in wheat genotypes. Afr. J. Biotech. 7(14): 2341-2352.

Egilla JN, Davies FT, Boutton Jr and Boutton TW (2005). Drought stress influences leaf water content, photosynthesis, and water-use efficiency of Hibiscus rosa-sinensis at three potassium concentrations. Photosynthetica, 43(1): 35-140.

FAO (Food and Agriculture Organization) (2004). Rice is Life. Italy: FAO.

Ghannoum O, Von Caemmerer S and Conroy JP (2002). The effect of drought on plant water use efficiency of nine NAD-ME and nine NADPME Australian C4 grasses. Functional Plant Biology, 29: 1337 - 1348.

Govindaraj M, Shanmugasundaram P, Sumathi P and Muthiah AR (2010). Simple, rapid and cost effective screening method for drought resistant breeding in Pearl Millet. Electronic Journal of Plant Breeding, 1(4): 590- 599.

Jaleel CA, Manivannan P, Lakshmanan GMA, Gomathinayagam $\mathrm{M}$ and Panneerselvam $\mathrm{R}$ (2008). Alterations in morphological parameters and photosynthetic pigment responses of Catharanthus roseus under soil water deficits. Colloids Surf. B: Biointerfaces, 61: 298-303.

Kaur G, Kumar S, Nayyar H and Upadhyaya HD (2008). Cold stress injury during the pod-filling phase in chickpea (Cicer arietinum L.): effects on quantitative and qualitative components of 
seeds. Journal of Agron. Crop Science, 194(6): 457-464.

Khush GS (2005). What it will take to Feed 5.0 Billion Rice consumers in 2030. Plant Molecular Biology, 59:1 - 6 .

Kumar RR, Karajol K and Naik GR (2011). Effect of polyethylene glycol induced water stress on physiological and biochemical responses in pigeon pea (Cajanus cajan L. Mill sp.). Recent Res. Sci. Tech. 3(1): 148-152.

Luma H, Qadir A and Hussein K Al-Ka'aby (2011). The effect of water stress on callus and somatic embryos formation of rice (Oryza sativa L.) cv. Jasmine cultured in vitro. Journal of Basrah Resear. (Sciences), Volume 37. Number 3.

Phung Thị, TH (2014). Physiological responses of rice seedlings under drought stress. Journal of Science \& Devel. 12(5): 635-640.

Rahbarian R, Khavari-Nejad R, Ganjeali A, Bagheri A and Najafi F (2011). Drought stress effects on photosynthesis, chlorophyll fluorescence and water relations in tolerant and susceptible Chickpea (Cicer Arietinum L.) genotypes. Acta. Biologica. Cracoviensia. Series Botanica, 53(1):47-56.
Rahimi A, Hosseinib SM, Pooryoosefc M and Fateh I (2010). Variation of leaf water potential, relative water content and SPAD under gradual drought stress and stress recovery in two medicinal species of Plantago ovata.

Rahdari P, Hosseini SM and Tavakoli S (2012). The study effect of drought stress on germination, proline, sugar, lipid,protein and chlorophyll content in purslane (Portulaca oleracea L.) leaves. J. Med. Plants Res. 6(9): 1539-1547.

Siddique MRB, Hamid A and Islam MS (2000). Drought stress effects on water relation of wheat. Bot. Bull. Acad. Sin. 41:35-39.

Thakur P, Kumar S, Malik JA, Berger JD and Nayyar H (2010). Cold stress effects on reproductive development in grain crops: an overview. Environ. Exp. Bot. 67(3): 429-443. 